\title{
THE EFFECT OF COUNTRY-OF-ORIGIN ON NEW ZEALAND CONSUMERS' BEER PURCHASING BEHAVIOR
}

\author{
Jashim Khan ${ }^{1 *}, \mathrm{Na} \mathrm{Zuo}^{2}$, Gary Rivers ${ }^{3}$ \\ ${ }^{1,3}$ University of Surrey, ${ }^{2}$ Digital Economy Consulting Centre, United Kingdom. \\ *Corresponding author; Email: j.a.khan@surrey.ac.uk
}

\begin{abstract}
Country of Origin (COO) sits along with marketing mix factor in the global market place. Given the importance of $\mathrm{COO}$, studies have touched the field of $\mathrm{COO}$ effects, though studies pertaining to alcoholic beverage purchase behavior, particularly in the New Zealand remains limited. This study explores the potential impact of demographics on the magnitude of Country of Origin effects for two lager beer products. The data was collected via survey format from 211 respondents living in Auckland, New Zealand. The results from this study suggest that older consumers are more dependent upon the country of origin information when evaluating a product and, particularly when presented with unfamiliar brands, they tend to perceive imported lager beer as being of higher quality, more trendy and more value for money. Also customer perceptions differ based on the customer's socio-economic status. Middle income customers are more likely to have favorable opinions about imported products, whereas, lower and higher income customers tend to have weaker views on this issue.
\end{abstract}

Keywords: Country-of-origin, lager beer, demographics, New Zealand.

\section{Introduction}

Country of Origin (COO) effects are stereotypes that consumers develop about countries. Consumers' impression about the country where the product was produced has an impact on the perceptions of the product itself. These impressions impact on whether consumers try, and adopt, the product. There are study in the context of durable products (see, for example, Ozden \& Maksudunov, 2012; Insch \& McBride, 2004; Liu \& Johnson, 2005), non-durable consumer goods (see, for example, Richardson, 2012; Schaefer, 1997); in terms of consumer purchasing behavior, i.e. business to consumer (Chao \& Rajendran, 1993) and industrial purchasing behavior, i.e. business to business (Dzever \& Quester, 1999). Apart from these general discussions, there seems to be a lack of research into factors which might influence $\mathrm{COO}$ effects, such as demographics, personality and situational variables (Schaefer, 1997). Previous research has identified the possible link between demographics and COO effects (Schooler, 1971; Schaefer, 1997). None to our knowledge examined the impact of demographics on the magnitude of $\mathrm{COO}$ effect of lager beer from the New Zealand perspective. This study attempts to fill this important gap by examining whether consumer demographics have an impact on the $\mathrm{COO}$ effects in the evaluation of alcoholic beverage such as lager beer. These products were chosen for a number of reasons. Firstly, most research has dealt with consumer durables, such as auto- mobiles (Liu \& Johnson, 2005) and televisions (Insch $\&$ McBride, 2004). Alcoholic beverages have not been given enough attention in this field of research. Secondly, the New Zealand markets for the chosen products contain a large number of foreign products. For instance, in terms of lager beers, imports represented $30 \%$ of the total premium lager volume sales in New Zealand during 2016 (Euromonitor, 2017).

\section{COO Effects and Demographics}

Some factors are thought to have potential influences on consumer behavior, such as consumers' brand knowledge (Brodie \& Benson-Rea, 2016), demographics (Schooler, 1971) and personality, situational variables, etc. (Schaefer, 1997). In an early study, Schooler (1971) investigated the effect of some demographic variables (i.e., age, gender, ethnicity and educational level) on foreign product evaluation by American consumers. He found that demographic variables can have an impact on consumers' evaluation processes. Greer (1971) suggested that older respondents tend to be influenced more by $\mathrm{COO}$ than the younger purchasing officers. Krishnakumar (1974) indicated that certain demographic variables (for example, gender and travel experience) accounted for significant differences in the Country of Origin effects among Indian consumers. Dornoff, Tankersley, and White (1974) examined consumers' perceptions of imported products including mechanical products, food products, fashion merchandise and electronic 
equipment. They also investigated the different perceptions across gender and educational level, and found that people with higher educational levels tend to have a more favorable attitude towards imports. Niffenegger, White, and Marmet (1980) study found that American products were more appealing to the younger consumers and French products were more favorable to the female consumers, while older consumers perceived British products more appealing. Heslop and Wall (1985) investigated COO and product image based on gender difference. The results indicated that females tend to have favorable impressions in terms of quality to products made in foreign countries except for South Korea, Hongkong and the Philippines. Al-hammad (1988) suggested that "there is a favorable correlation between age and income in terms of price and quality evaluation of products". Also, it was found that there is a relationship between the level of education and the perceptions of imported products (Brodie \& Benson-Rea, 2016). In 1997, Schaefer conducted a study in the UK to determine the potential impact of consumers' age, socio-economic status and gender on the $\mathrm{COO}$ effect in evaluation of alcoholic beverage products. She found that older consumers show stronger $\mathrm{COO}$ effects. She also found that the lower socio-economic group showed stronger country of origin effects for sparkling wine, whereas, the higher socio-economic group showed stronger $\mathrm{COO}$ effects for lager beer. Balabanis and Siamagka (2017) confirm that product category is an important determinant of the behavioral effects of consumer ethnocetrism. Given the fact that product category influence country of origin effect, this research aims to study alcoholic beverage, such as beer and examines the role of age, socio-economic and gender on the $\mathrm{COO}$ effect that differs between regions, therefore we propose that:

$P_{1}$ : There will be no differences across age groups regarding the use of $\mathrm{COO}$ in product evaluation in New Zealand.

$P_{2}$ : There will be no differences across socioeconomic status in the use of $\mathrm{COO}$ in product evaluation in New Zealand.

$P_{3}$ : There will be no differences across gender in the use of $\mathrm{COO}$ in product evaluation in New Zealand.

\section{Research Method}

The study drew its sample entirely from the residents of Auckland city due to several considerations. Firstly, Auckland is the biggest city in New Zealand, comprising one third of New Zealand's total population (New Zealand Census, 2001). Secondly,
Auckland is a multicultural city with a larger number of immigrants than most other areas, and it is also the most important commercial and trade centre in New Zealand. A mall intercept survey method was adopted. In total, 405 respondents were approached and 211 usable questionnaires have been collected from qualifying respondents.

The questionnaire used in this study was adapted from Schaefer's study (1997) with required amendments to suit research purpose. The questionnaire contains three sections. In Section I, respondents are asked to rate selected imported brands of lager beer on the basis of three factors. These are the overall quality, trendiness and value for money of the products. Section II asks the respondents to judge the overall quality of lager produced in selected countries by providing only the product $\mathrm{COO}$ cue and section III asks for the respondents' demographic data; that is, age, socio-economic status and gender; in order to analyse the impact of demographic variables on the country of origin effect. Seven-point scales were used to measure customers' opinions of each dimension, where 1 = very bad quality/not trendy at all/very bad value for money, and $7=$ very good quality/very trendy/very good value for money.

In total, $47 \%$ of respondents are aged 18-24 years old, $8.9 \%$ of respondents are over 55 years. The 25-34 year old group and the 35-55 year old group make up $22.3 \%$ and $21.78 \%$ of the total sample population, respectively. In terms of income, $49.7 \%$ of the respondents are classified as being of middle income with a yearly gross income between NZ $\$ 20,001$ and NZ $\$ 60,000,34.7 \%$ of respondents are from the low income group, with gross yearly income of less than NZ $\$ 20,000$. The remainder of the respondents $(15.4 \%)$ are from the high socio-economic class, with above NZ\$60,001 in yearly gross income.

In order to examine the research propositions, Pearson correlation testing and sign testing was utilised. Pearson correlation was used to examine the correlations between brands and the country of origin. Thirdly, in order to examine the significant difference between different demographic variables, a sign test was used to compare the differences between respondents from different age groups, socio-economic groups and genders, based on the correlations retrieved from the previous testing.

\section{Result and Discussion}

In order to investigate the differences in the ratings by each age group, sign tests were used to test the existence of differences and significance. Sign tests results based on data indicate that there was a 
significant difference in ratings by 18-24 year old respondents and 35-54 year old respondents, as $p=0.035$. More specifically, 35-54 year old respondents show stronger correlations overall than do 1824 year olds when unfamiliar brands were given. Significant differences also exist between the results between the 25-34 year old and the over 55 year old groups of respondents, as $p=0.035$. More specifically, the over 55 year old respondents show stronger overall correlations than do the 25-34 year old respondents. No significant differences were found between other age groups in the strength of the correlations between brand and country ratings. Therefore, proposition that there will be no differences across age groups in the use of $\mathrm{COO}$ in product evaluation in New Zealand, is partially rejected based on the data.

Sign test results indicate that, overall, there is no significant difference in the ratings across all socioeconomic groups based on the lager beer data. To sum up, in the lager beer data, there are no significant differences found between the low and middle socioeconomic groups $(p=0.302)$, the low and high socioeconomic groups $(p=0.302)$ and the middle and high socio-economic groups (1.00), respectively. Therefore, proposition 2 is accepted on the basis of the lager beer data. In order to investigate the differences of ratings across gender indicate that there was a significant difference in the ratings by female respondents and male respondents, as $p=0.035$. No significant differences were found between females and males in the strength of the correlations between brand and country ratings, when unfamiliar brands were given. Hence, proposition 3, there will be no differences across gender in the use of $\mathrm{COO}$ in product evaluation in New Zealand, is partially rejected according to the data analysis. The sign test is used to test the significant difference between males and females in terms of lager beer. The differences are found to be significant for 'familiar brand' $(p=.035)$ and insignificant for 'unfamiliar brand' (118).

\section{Conclusion}

The findings of this study suggest that certain demographic variables, such as age and socio-economic grouping, may affect the extent to how much they rely on $\mathrm{COO}$ in the product evaluation process regarding lager beer in New Zealand. Apart from that, the impact of gender on $\mathrm{COO}$ effects is mixed and unclear. In terms of the impact of age on the magnitude of $\mathrm{COO}$ effects it is concluded that, as consumers' age increases, the extent of reliance on country of origin information also increases. Older consumers tend to rely more on $\mathrm{COO}$ information than do younger ones, particularly when brand image is absent. This may be because older people have developed stereotypes towards certain countries, which are fixed and difficult to change. For instance, older consumers might perceive German beer overall as being of good quality, without knowing the brands. This finding is consistent with the previous study conducted by Schaefer (1997). She also found that older consumers seem to show stronger country of origin effects than younger consumers. In conclusion, some demographic variables can have an influence on the magnitude of country of origin effects. For instance, age and socio-economic class can definitely influence the extent to how much respondents rely on $\mathrm{COO}$ effects.

\section{References}

Al-hammad, A. A. (1988). A study of the Saudi Arabian market for selected imported manufactured goods-an economic cultural and attitudinal analysis with particular references to UK suppliers. $\mathrm{PhD}$ thesis, University of Bradford, UK.

Balabanis, G. \& Siamagka, N. T. (2017). Inconsistencies in the behavioral effects of consumer ethnocentrism: The role of brand, product category and country of origin. International Marketing Review, 34(2), 166-182.

Brodie, R. J. \& Benson-Rea, M. (2016). Country of origin branding: An integrative perspective. Journal of Product \& Brand Management, 25(4), 322-336.

Chao, P. \& Rajendran, K. N. (1993). Consumer profiles and perceptions: Country-of-origin effects. International Marketing Review, 10(2), 22-40.

Dornoff, R., Tankersley, C., \& White, G. (1974). Consumers' perceptions of imports. Akron Business and Economic Review, 5(Summer), 26-29.

Dzever, S. \& Quester, P. (1999). Country-of-origin effects on purchasing agents' product perceptions: An Australian perspective. Industrial Marketing Management, 28(2), 165-175.

Euromonitor. (2017). Alcoholic drinks in New Zealand/country report/Jan 2016. Retrieved 10 May, 2017 from www.euromonitor.com.

Greer, T. V. (1971). British purchasing agents and European Economic Community: Some empirical evidence on international industrial perceptions. Journal of Purchasing, 7(2), 56-63.

Heslop, L. A. \& Wall, M. (1985). Differences between men and women in the country of origin product images. Administrative sciences association of Canada proceeding. Montreal, Canada, 148-158. 
Insch, G. S. \& McBride, J. B. (2004). The impact of country-of-origin cues on consumer perceptions of product quality: A binational test of the decomposed country of origin construct. Journal of Business Research, 57(3), 256-265.

Krishnakumar, P. (1974). An exploratory study of influence of country of origin on the product image of persons from selected countries. $\mathrm{PhD}$ Dissertation, University of Florida.

Liu, S. S. \& Johnson, K. F. (2005). Country-of-origin effects on brand judgments. Journal of Advertising, 34(1), 87-97.

New Zealand Census. (2001). 2001 Census of population and dwellings statistics New Zealand, 2001. Retrieved from http://www.nzstats.auckland.ac.nz/browse/subject/?sindex=P\&sid=283 $\&$ subsid $=283 \&$ stype $=1 \&$ s na me $=$ Population .
Niffenegger, P., White, J., \& Marmet, G (1980). How British retail managers view French and American products. European Journal of Marketing, 14(8), 493-498.

Ozden, K. \& Maksudunov, A. (2012). The importance of country of origin on purchasing durable consumer goods: In case of Kyrgyzstan. American International Journal of Contemporary Research, 2(2), 143-148.

Schaefer, A. (1997). Do demographics have an impact on country of origin effects? Journal of Marketing Management, 13(8), 813-834.

Schooler, R. D. (1971). Bias phenomena attendant to the marketing of foreign goods in the U.S. Journal of International Business Studies, 2(1), 71-80. 